\title{
Pengaruh Pemberian Ekstrak Biji Melinjo (Gnetum gnemon) Terhadap Kadar Kolesterol LDL Pada Tikus Galur Wistar (Rattus norvegicus) Model Hiperkolesterolemia
}

\author{
Dita Viviant Sagith ${ }^{1}$, Cimi IImiawati ${ }^{2}$, Yusticia Katar ${ }^{3}$
}

\begin{abstract}
Abstrak
Melinjo (Gnetum gnemon) merupakan tumbuhan asli Indonesia yang mudah diperoleh dan ekstrak biji melinjo mengandung berbagai macam stilbenoid yang tergolong senyawa resveratrol beserta turunannya. Penelitian terdahulu menunjukkan bahwa resveratrol dapat menurunkan kadar kolesterol LDL serum melalui penghambatan HMG-KoA reduktase. Tujuan penelitian ini adalah meneliti pengaruh pemberian ekstrak biji melinjo terhadap penurunan kadar kolesterol LDL pada tikus yang diberi diet tinggi lemak. Penelitian ini menggunakan rancangan randomized pre-post test control group design yang terdiri dari lima kelompok $(n=5)$. Diet tinggi lemak diberikan berupa pakan otak sapi selama 29 hari (2 ml/hari). Kelompok perlakuan diberi ekstrak biji melinjo dosis 250, 500, dan $2000 \mathrm{mg} / \mathrm{kgbb} / \mathrm{hari}$. Ekstrak biji melinjo mulai diberikan hari ke-16 sampai hari ke-29. Kadar kolesterol LDL serum diperiksa dengan spektrofotometer. Data dianalisis dengan paired sample t-test dan One-Way ANOVA. Hasil paired sample t-test menunjukkan terdapat penurunan bermakna kadar kolesterol LDL serum setelah pemberian ekstrak biji melinjo pada kelompok yang mendapat dosis $2000 \mathrm{mg} / \mathrm{kgbb} / \mathrm{hari}(\mathrm{p}=0,003)$, sedangkan pada dosis lain tidak terdapat penurunan LDL serum yang bermakna. Uji One-Way ANOVA antar kelompok perlakuan menunjukkan tidak terdapat perbedaan kadar kolesterol LDL serum yang bermakna $(p=0,531)$. Disimpulkan bahwa pemberian ekstrak biji melinjo dapat menurunkan kadar kolesterol LDL serum pada tikus yang diinduksi diet tinggi lemak pada dosis $2000 \mathrm{mg} / \mathrm{kgbb} / \mathrm{hari}$.
\end{abstract}

Kata kunci: kolesterol, LDL, melinjo

\begin{abstract}
Melinjo (Gnetum gnemon) is an Indonesian endemic plant frequently consumed as vegetable and melinjo seed extract contains various stilbenoids of resveratrol compound and its derivatives. Previous studies showed that resveratrol may lower serum LDL-cholesterol level by inhibiting HMG-CoA reductase. The objective of this study was to examine the effect of melinjo seed extract on lowering serum LDL-cholesterol level in high fat diet-fed rats. This study used randomized pre-post test control group design consisted of five groups $(n=5)$ of male wistar rats (Rattus norvegicus). High fat diet was given in the form of bovine brain suspension for 29 days (2 ml/day). Melinjo seed extract was given to each treatment group in a daily dose of 250, 500, $2000 \mathrm{mg} / \mathrm{kgbw}$, consecutively, from day 16 to 29. Serum LDL-cholesterol was measured by spectrophotometer. Data were analized by paired sample t-test and OneWay ANOVA. Paired sample t-test showed that in the group given melinjo seed extract at a daily dose 2000 $\mathrm{mg} / \mathrm{kg}$ bw/day there was a statistically significant decrease in serum LDL-cholesterol level ( $p=0.003)$. One-Way ANOVA test showed no differences in serum $L D L$-cholesterol among treatment groups $(p=0.531)$. It is concluded that melinjo seed extract at the dose of $2000 \mathrm{mg} / \mathrm{kgbw} /$ day can lower serum LDL-cholesterol level in high fat diet-fed rats.
\end{abstract}

Keywords: cholesterol, LDL, melinjo

Afiliasi penulis: 1. Prodi Kedokteran Fakultas Kedokteran Universitas Andalas (FK Unand) Padang. 2. Bagian Farmakologi dan Terapi FK Unand,
Korespondensi: Dita Viviant Sagith, Email: sagithdita@gmail.com. Telp: 087895031666. 


\section{PENDAHULUAN}

Kadar kolesterol LDL serum yang tinggi dalam waktu yang lama dapat menyebabkan terbentuknya aterosklerosis, yaitu penebalan dan pengerasan dinding pembuluh darah yang berlangsung secara progresif akibat penimbunan plak kolesterol pada lapisan tunika intima arteri yang dapat menghambat aliran darah, sehingga mengakibatkan penyakit serebrovaskular, kardiovaskular dan jantung koroner. $^{1,2,3}$

WHO melaporkan bahwa penyakit kardiovaskular menjadi penyebab dari 30\% kematian di seluruh dunia dan diprediksi akan menjadi penyebab utama kematian di dunia pada dua dekade ke depan. ${ }^{4}$ Angka kematian akibat gangguan kardiovaskular diperkirakan akan meningkat menjadi 25 juta orang pada tahun 2020 , atau sekitar $37 \%$ dari total kematian yang diperkirakan dan $45 \%$ dari kematian tersebut disebabkan oleh penyakit jantung koroner. ${ }^{5,6}$ Kondisi penyakit jantung koroner di Indonesia berada pada posisi ketujuh tertinggi dalam kategori penyakit tidak menular dan prevalensi penyakit jantung koroner di Sumatera Barat menurut diagnosis dan gejala adalah $1,2 \%{ }^{7}$

Kolesterol LDL merupakan lipoprotein utama yang bersifat aterogenik dan dijadikan target terapi dalam memperbaiki profil lipid serum. ${ }^{1,8}$ Terapi farmakologi yang sering digunakan dalam terapi adalah jenis HMG-CoA reductase inhibitor (statin), tetapi penggunaan obat-obatan tersebut dapat menimbulkan efek samping. ${ }^{9}$ Terapi non-farmakologi yang dikenal juga dengan modifikasi gaya hidup dapat dilakukan dengan terapi modifikasi diet, aktivitas fisik, berhenti merokok, mengurangi berat badan berlebih serta mengurangi asupan alkohol. ${ }^{10,11}$ Salah satu terapi modifikasi diet yang bisa dilakukan adalah konsumsi sayuran yang gizinya seimbang untuk mencegah tingginya kadar lipid. ${ }^{11}$ Penggunaan bahan alami seperti konsumsi buah, sayuran, atau bahan alami lainnya dalam modifikasi diet menjadi meningkat sehingga eksplorasi terhadap bahan-bahan alam yang dapat berfungsi sebagai penurun dan pencegah naiknya kadar lemak darah semakin giat dilakukan. $^{11,12,13}$
Melinjo (Gnetum gnemon) merupakan tanaman asli berasal dari Asia Tenggara dan Melanesia. ${ }^{12,13,14}$ Di Indonesia dikenal dengan nama melinjo, melingo atau bagoe. Biji melinjo sering dikonsumsi dalam bentuk sayur atau dijadikan emping yang dihasilkan melalui proses penghancuran biji lalu dikeringkan dan digoreng. ${ }^{14}$ Khasiat melinjo sudah banyak diteliti, terutama mengenai kandungan bioaktifnya. Melinjo mengandung senyawa stilbenoid dan turunannya termasuk didalamnya senyawa resveratrol yang mempunyai banyak manfaat sebagai antioksidan terhadap tubuh. Pada penelitian terdahulu dilaporkan bahwa ekstrak biji melinjo dapat menurunkan level asam urat, menghambat enzim lipase di pankreas dan a-amilase, serta meningkatkan kadar level HDL kolesterol secara signifikan. ${ }^{15}$

Salah satu manfaat yang diketahui mengenai efektivitas ekstrak biji melinjo dalam menurunkan kadar profil lipid adalah dengan menghambat aktivitas enzim HMG-CoA (3-hydroxy-3-methylglutarylcoenzyme $A)$ reduktase. ${ }^{14}$ Penghambatan aktivitas HMG-CoA reduktase akan menurunkan sintesis kolesterol dan meningkatkan jumlah reseptor LDL yang terdapat dalam membran hati dan jaringan ekstrahepatik. ${ }^{15}$ Berdasarkan permasalahan tersebut, serta dari literatur yang belum ada penelitian yang dilakukan mengenai efek ekstrak biji melinjo terhadap penurunan kadar kolesterol LDL, sehingga mendorong peneliti untuk melakukan penelitian mengenai pengaruh pemberian ekstrak biji melinjo terhadap penurunan kadar kolestrol LDL serum pada tikus wistar (Rattus norvegicus).

\section{METODE}

Eksperimen dilakukan dengan rancangan pre post test randomized control group design yang terdiri dari 5 kelompok hewan coba sebagai subjek penelitian yaitu 1 kelompok kontrol negatif, 1 kelompok kontrol positif dan 3 kelompok perlakuan.

Pemeliharaan, perlakuan dan pengukuran berat badan hewan coba dilakukan di animal house Fakultas Kedokteran Universitas Andalas. Pengukuran kadar kolesterol LDL serum dilakukan di Laboratorium Biokimia Fakultas Kedokteran Universitas Andalas. 
Hewan coba pada penelitian adalah tikus putih jantan (Rattus norvegicus) galur Wistar yang berumur 8-12 minggu dengan berat badan berkisar 150-300 gram. Banyaknya hewan coba minimal yang dibutuhkan dalam penelitian ini berdasarkan kriteria World Health Organization (WHO) yaitu sebanyak 5 ekor tikus untuk setiap kelompok. ${ }^{16}$ Total hewan coba untuk 5 kelompok adalah 25 ekor tikus. Prediksi hewan coba yang drop out adalah sebesar $10 \%$. Maka hewan coba ditambah satu ekor untuk setiap kelompok. Sehingga total hewan coba yang dibutuhkan untuk lima kelompok adalah 30 ekor tikus. Induksi hiperkolesterolemia dilakukan dengan pemberian suspensi otak sapi sesuai metode dari penelitian terdahulu. ${ }^{17}$ Kelompok kontrol negatif (K-) hanya mendapat pakan standar selama 29 hari. Kelompok kontrol positif $(\mathrm{K}+)$ dan kelompok perlakuan (P1, P2, P3) diberi pakan standar dan suspensi otak sapi 2 $\mathrm{ml} /$ hari selama 29 hari. ${ }^{17}$ Kelompok perlakuan (P1, P2, P3) diberi ekstrak biji melinjo 250, 500, dan 2000 $\mathrm{mg} / \mathrm{kgBB}$, berturut - turut, pada hari ke-16 hingga 29 (14 hari).

Pengukuran kolesterol LDL serum dilakukan dengan metode CHOD PAP Enzymatic Photometric Test (DiaSys ${ }^{\mathrm{TM}}$, Germany) dan hasilnya dinyatakan dalam mg/dl.

Hasil pemeriksaan kadar kolesterol LDL serum tikus sebelum dan sesudah perlakuan pada masingmasing kelompok selanjutnya dianalisis secara statistik. Pengujian yang pertama kali dilakukan adalah uji normalitas data menggunakan Saphiro-Wilk test, dilanjutkan dengan paired sample t-test untuk mengetahui perbedaan rerata sebelum dan setelah perlakuan. Perbedaan rerata antar kelompok sebelum dan sesudah pemberian ekstrak biji melinjo, dianalisis dengan uji One-Way ANOVA.

\section{HASIL}

Pemberian suspensi otak sapi untuk induksi hiperkolesterolemia pada tikus wistar hanya berhasil pada kelompok $\mathrm{P} 1$ sebagaimana yang tampak pada Grafik 1 (One-Way ANOVA dengan uji post hoc Tukey, $\mathrm{p}=0,014)$. Pemberian ekstrak biji melinjo pada hari ke16 hingga 29 menimbulkan penurunan kadar kolesterol LDL serum yang bermakna hanya pada kelompok P3 (paired sample t-test, $\mathrm{p}=0,003$ )

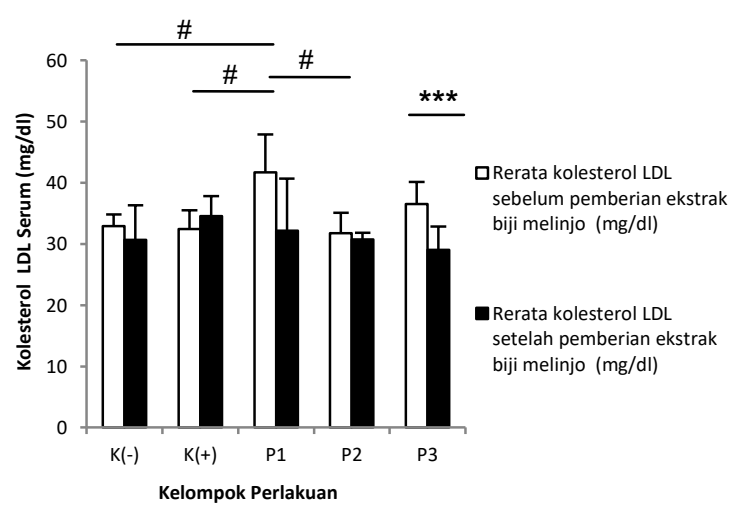

Grafik 1. Rerata kadar kolesterol LDL serum tikus wistar setelah induksi hiperkolesterolemia dan sesudah pemberian ekstrak biji melinjo. $\mathrm{K}(-)=$ kelompok kontrol negatif, $\mathrm{K}(+)=$ Kelompok kontrol positif, $\mathrm{P} 1=$ kelompok perlakuan pertama dosis $250 \mathrm{mg} / \mathrm{kgbb}, \mathrm{P} 2$ = kelompok perlakuan kedua dosis $500 \mathrm{mg} / \mathrm{kgbb}, \mathrm{P} 3$ = kelompok perlakuan ketiga dosis 2000 $\mathrm{mg} / \mathrm{kgbb}$. ${ }^{* * *} \mathrm{p}<0,001$ (paired Sample t-test), ${ }^{\#} \mathrm{p}<0,05$ (OneWay ANOVA).

Grafik 1 menunjukkan rerata kadar kolesterol LDL serum tikus yang diberikan pakan otak sapi dan intervensi ekstrak biji melinjo. Rerata kadar kolesterol LDL sebelum diberi perlakuan dengan ekstrak biji melinjo dengan rerata tertinggi dan terendah terdapat pada kelompok P1 dengan rerata kelompok adalah 41,72 mg/dl dan kelompok P2 dengan nilai 31,78 $\mathrm{mg} / \mathrm{dl}$. Rerata kadar kolesterol LDL setelah diberi perlakuan dengan ekstrak biji melinjo pada tikus model hiperkolesterolemia tertinggi dan terendah terdapat pada kelompok $\mathrm{K}(+)$ dengan rerata kelompok 34,58 $\mathrm{mg} / \mathrm{dl}$ dan kelompok K(-) yaitu 30,64 mg/dl.

\section{PEMBAHASAN}

Induksi hiperkolesterolemia hanya berhasil pada kelompok $\mathrm{P} 1$ karena adanya perbedaan yang bermakna dengan kelompok kontrol negatif, tetapi seluruh kelompok telah menunjukkan kadar kolesterol LDL serum dalam kondisi hiperkolesterolemia dengan nilai $\geq 27,2 \mathrm{mg} / \mathrm{dl} .{ }^{17} \mathrm{Hal}$ ini sesuai dengan penelitian terdahulu yang melaporkan bahwa otak sapi dapat meningkatkan kadar kolesterol LDL serum pada tikus sebesar $\geq 19.92 \%$. $^{17}$

Rerata kadar kolesterol LDL serum setelah pemberian ekstrak biji melinjo pada kelompok P1 dan P2 menunjukkan terdapat penurunan tetapi penurunan kadar kolesterol LDL serum menunjukkan hasil yang 
tidak bermakna. Hasil uji paired sample t-test pada P1 dan P2 juga sesuai dengan penelitian terdahulu pada tikus yang melaporkan bahwa ekstrak biji melinjo pada dosis $0-1000 \mathrm{mg} / \mathrm{kg} / \mathrm{bb}$ tidak menimbulkan penurunan yang signifikan terhadap kadar kolesterol total, trigliserida dan tidak dilaporkan kadar LDL setelah pemberian ekstrak biji melinjo. ${ }^{18}$

Rerata kadar kolesterol LDL serum pada P3 menunjukkan penurunan sebesar $20,42 \%$ dan nilai rerata kolesterol LDL P3 yaitu 29,06 belum mencapai nilai normal kadar kolesterol LDL tikus yaitu $<27,2$ $\mathrm{mg} / \mathrm{dl}{ }^{17,19}$ Hasil uji paired sample $t$-test kelompok P3 menunjukkan penurunan kadar kolesterol LDL serum yang bermakna. Penurunan kadar kolesterol LDL pada penelitian ini dapat disebabkan karena ekstrak biji melinjo mengandung berbagai macam stilbenoid termasuk trans-resveratrol (3,5,4'-trihydroxy-transstilbene), gnetin $C$ (GC; resveratrol dimer), gnetin $L$ (turunan GC), gnemoside A (GC-diglucoside), gnemoside $C$ (GC-monoglucoside) dan gnemoside D (GC-monoglucoside). ${ }^{13,14,15,20}$ Penelitian terdahulu mengenai pengaruh resveratrol terhadap dislipidemia dan diabetes mengatakan bahwa penurunan kadar kolesterol pada setiap kelompok kemungkinan berhubungan dengan kandungan resveratrol yang dimiliki oleh ekstrak biji melinjo. Mekanisme resveratrol dalam menurunkan kolesterol LDL serum adalah melalui proses fosforilase atau pengaktifan dari 5'AMP-protein pengaktif kinase (AMPK) yang akan menghambat asetil-KoA karboksilase untuk menghambat oksidasi asam lemak dan menekan sintesis kolesterol. ${ }^{21}$

Hal lain yang dapat menjadi faktor terhadap penurunan kolesterol LDL serum kemampuan inhibitor HMG-KoA reduktase pada ekstrak biji melinjo untuk menurunkan proses sintesis kolesterol LDL. Penelitian terdahulu mengenai pengaruh ekstrak biji melinjo secara in silico terhadap kolesterol melaporkan bahwa inhibitor HMG-KoA reduktase bekerja menghambat sintesis kolesterol pada jalur mevalonat dan juga menurunkan sintesis Apo B100 serta meningkatkan jumlah reseptor kolesterol LDL di permukaan hati. Proses ini akan mengakibatkan kolesterol LDL kembali ditarik dari jaringan ke hati. ${ }^{14}$

\section{SIMPULAN}

Ekstrak biji melinjo berpotensi menurunkan kadar kolesterol LDL serum.

\section{DAFTAR PUSTAKA}

1. Perkumpulan Endokrinologi Indonesia (Perkeni). Panduan pengelolaan dislipidemia di Indonesia. Indonesia:Perkeni; 2015.

2. National Institutes of Health. ATP III guidelines at a glance quick desk reference. National Institutes of Health Department of Health and Human Services. 2001 (diunduhSeptember 2017). Tersedia dari: https://www.nhlbi.nih.gov/files/docs/guidelines/atgla nce.pdf

3. Botham KM, Mayes PA. Lipid transport and storage. Dalam: Murray RK, Bender DA, Botham KM, Kennelly PJ, Rodwell VW, Weil PA, editor (penyunting). Harper's illustrated biochemistry. Edisi ke-29. The McGraw-Hill education; 2012.hlm. 237-59.

4. World Health Organization (WHO). Cardiovascular disease fact sheet No. 317.2013 (diunduh September 2017). Tersedia dari:http://www.who.int/ mediacentre/factsheets/fs317/en/index.html

5. World Health Organization (WHO). Global status report on noncommunicable diseases 2014 (diunduh September 2018). Tersedia dari: http://www.who.int/nmh/publications/ncd-statusreport-2014/en/

6. Kementerian Kesehatan RI. Situasi kesehatan jantung. 2014. Pusat Data dan Informasi (diunduh Desember 2017). Tersedia dari: http://www. depkes.go.id/resources/download/pusdatin/infodati n/infodatin-jantung.pdf

7. Badan Pengembangan dan Penelitian Kesehatan Kementrian RI. Riset kesehatan dasar (Riskesdas). 2013 (diunduh September 2017). Tersedia dari: http://www.depkes.go.id/resources/download/gener al/Hasil\%20Riskesdas\%202013.pdf

8. Perhimpunan Dokter Spesialis Kardiovaskular Indonesia. Pedoman Tatalaksanan Dislipidemia. Centra Communicans. 2015:1:1-13 (diunduh Desember 2017). Tersedia dari: http://www. inaheart.org/upload/file/Pedoman tatalksana Disli pidemia.pdf 
9. Adam John MF. Dislipidemia. Dalam: Setiati $S$, Alwi I, Sudoyo AW, K Marcellus Simadibrata, Setiyahadi B, Syam AF, editor (penyunting). Buku ajar ilmu penyakit dalam jilid I. Edisi ke-6. Jakarta: Interna Publishing; 2014.hlm.2549-58.

10. Jones PJ. Clinical nutrition: functional foods-more than just nutrition. CMAJ. 2002;166:1555-63.

11. Dachriyanus DO, Katrin RO, Oktarina O, Ernas, Suhatri, MH Mukhtar. Uji Efek A-mangostin terhadap kadar kolesterol total, trigliserida, kolesterol HDL, dan kolesterol LDL darah mencit putih jantan serta penentuan lethal dosis $50\left(\mathrm{Ld}^{50}\right)$. J Sains Tek Far. 2007;12(2):64-72.

12. Wong DH, Villanueva JA, M DV, Cress AB, Sokalska A, Ortega I, Duleba AJ. Resveratrol inhibits the mevalonate pathway and potentiates the antiplorifetarive effects of simvastatin in rat theca-interstitial cells. Int J Fertil Steril. 2011; 96 (5):1252-58.

13. Ayuningtias NI, Rahmawati M, Sutriyo, Mun'in A. Optimization of ionic liquid-based microwave assisted extraction to Obtain Trans-resveratrol from Gnetum gnemon L. Seeds. J Young Pharm. 2017; $9(4): 457-62$.

14. Hafidz KA, Puspitasari N, Azminah, Yanuar A, Artha $Y$, Mun'im A. HMG-CoA reductase inhibitory activity of gnetum gnemon seed extract and identification of potential inhibitors for lowering cholesterol level. J Young Pharm. 2017; 9(4): 55965.

15. Konno $H$, Kanai $Y$, Katagiri M, Watanabe $T$, Mori A, Ikuta T, et al. Melinjo (Gnetum gnemon L.) Seed extract decreases serum uric acid levels in nonobese Japanese males: a randomized controlled study. Evidence-Based Complementary and Alternative. 2013;589169.

16. World Health Organization (WHO). General guideline for methodologies on research and evaluation of traditional medicine. Geneva: WHO; 2000 (diunduh Desember 2017). Tersedia dari: http://www.who.int/iris/handle/10665/66783

17. Towil AS, Pramono A. Pengaruh pemberian yoghurt simbiotik tanpa lemak ditambah tepung gembili terhadap kadar kolesterol LDL tikus hiperkolesterolemia. Jurnal Gizi Indonesia. 2014; 3(1): 135-40.

18. Tatefuji T, Yanagihara M, Fukushima S, Hashimoto K. Safety assessment of melinjo (Gnetum gnemon L.) seed extract: acute and subchronic toxicity studies. Food Chem Toxicol. 2014;67:230-35.

19. Mayasari DR, Rahayuni A. Pengaruh pemberian serbuk biji labu kuning (Cucurbita moschata) terhadap penurunan kolesterol LDL pada tikus wistar hiperkolesterolemia. J Nutrition College. 2014;3(4);432-9.

20. Ikuta T, Saito S, Tani H, Tatefuji T, Hashimoto K. Resveratrol derivative-rich melinjo (Gnetum gnemon L.) seed extract improves obesity and survival of C57BL/6 mice fed a high-fat diet. Biosci Biotech Bioch. 2015; 79(12): 2044-49.

21. Shahi MM, Haidari F, Shiri MR. Comparison of effect of resveratrol and vanadium on diabetes related dyslipidemia and hyperglycemia in streptozotocin induced diabetic rats. Adv Pharm Bull. 2011;1(2):81-6. 